\title{
Correction: Hospital safety net burden is associated with increased inpatient mortality and postoperative morbidity after total hip arthroplasty: a retrospective multistate review, 2007-2014
}

La M, Tangel V, Gupta S, et al. Hospital safety net burden is associated with increased inpatient mortality and postoperative morbidity after total hip arthroplasty: a retrospective multistate review, 2007-2014. Reg Anesth Pain Med 2019;44:839-46. doi:10.1136/rapm-2018100305.

Figure 1 should be figure 2 and vice versa. The footnotes are correct. This has been corrected online.

(C) Author(s) (or their employer(s)) 2020. No commercial re-use. See rights and permissions. Published by BMJ. Reg Anesth Pain Med 2020;45:e2. doi:10.1136/rapm-2018-100305corr1

D) Check for updates 